\title{
Xakriabá interpelado: indianidade, mistura e fronteiras da colonialidade
}

\author{
Alessandro Roberto de Oliveira \\ Universidade Federal de Goiás - UFG \\ e-mail: alessandro.robertodeoliveira@gmail.com
}

\begin{abstract}
Resumo
Este artigo aborda o impacto da mistura nas concepções interétnicas acerca da indianidade. $\mathrm{O}$ foco etnográfico é um episódio de interpelação à identidade de um lavrador Xakriabá. Este fato aconteceu em uma situação histórica na qual o movimento indígena começou a desestabilizar a colonialidade do poder no município de São João das Missões, no norte de Minas Gerais. O objetivo do texto é analisar este evento através de uma aproximação entre os estudos sobre relações interétnicas realizados no Brasil e alguns aportes do pensamento social latino-americano.
\end{abstract}

Palavras-chave: indianidade, mistura, colonialidade do poder, fronteiras.

\begin{abstract}
This article approaches the impact of the mixture in interethnic conceptions about the indigeneity. The ethnographic focus is an episode of interpellation towards the identity of a Xakriabá peasant. This fact happened in a historical situation that the indigenous movement has started to destabilize the coloniality of the local power in the city of São João das Missões, at the North of Minas Gerais state. The article aims to analyze this event through an approximation between the studies about interethnic relations in Brazil and some contributions of the Latin American social thought.
\end{abstract}

Keywords: indigeneity, mixture, coloniality of power, boundaries.

\section{Introdução}

No início de 2004 desembarquei no município de São João das Missões com o objetivo de fazer pesquisa junto ao povo Xakriabá. Aquele foi um ano de eleições municipais e no momento em que eu iniciava o trabalho de campo, professores indígenas estavam começando a colocar em prática um projeto político arrojado: mobilizar suas comunidades para conquistar o poder executivo e a hegemonia étnica no legislativo local do munícipio de São João das Missões. ${ }^{1}$

\footnotetext{
${ }^{1}$ No início de 2004 desembarquei no município de São João das Missões enquanto estudante de graduação em Ciências Sociais pela Universidade Estadual de Montes Claros. Inspirado na leitura de "O Índio e o Mundo dos Brancos" (CARDOSO DE OLIVEIRA 1996), meu interesse era interpretar como os "brancos" viam os Xakriabá enquanto "índios", como os Xakriabá viam a si mesmos como "índios", e como viam a si mesmos com os olhos dos "brancos". Na dissertação de mestrado (OLIVEIRA 2008) focalizei essas dinâmicas da identidade entrecruzavam a política indígena - entendida como a prática política baseada na organização social e na história de luta pelo reconhecimento de sua identidade étnica e de direitos desse povo - e a política tal qual é praticada nas disputas pelo controle de espaços de poder institucional.
} 
Naquele contexto político realizei entrevistas com indígenas e "brancos" para saber como as relações interétnicas eram percebidas de ambos os lados da fronteira. Umas destas entrevistas com um comerciante não indígena deslizou para confronto interétnico no qual presenciei a interpelação à identidade de um lavrador Xakriabá. Neste artigo apresento esta situação com o objetivo de refletir sobre o impacto da mistura nas concepções indígenas e regionais acerca da indianidade e de como a racialidade está presente nas relações interétnicas. Ao desenvolver a análise, este texto pretende chamar atenção para como as questões sobre colonialidade do poder, terra e identidade trabalhadas por alguns intelectuais do pensamento social latino-americano encontram ressonância na história teórica dos estudos sobre relações interétnicas realizados no Brasil.

Para analisar esse evento etnográfico e aproximar esses diálogos teóricos realizo três movimentos. Começo com um esboço de algumas concepções desenvolvidas no pensamento social latino-americano, tomando como eixo as elaborações de Aníbal Quijano sobre a "colonialidade do poder" e o "problema indígena" na América Latina e de Nina Pacari, uma intelectual indígena quéchua que reflete sobre a dinâmica das identidades indígenas.

Em seguida, apresento um breve quadro histórico desse "problema" no norte de Minas, em que a terra é o elemento fundamental nas ondas de colonização e também do movimento de reafirmação da identidade étnica pelos Xakriabá. $O$ terceiro movimento é a textualização do confronto entre o comerciante "branco" e o lavrador indígena. Ao explorar o teor desse embate, ressalto as imagens da mistura presente nos diferentes pontos de vista locais frente às mudanças no padrão de poder entre índios e não índios na região.

\section{Colonialidade do poder e identidade como resposta política}

O sociólogo peruano Aníbal Quijano é um dos intelectuais mais reconhecidos e influentes no campo dos estudos decoloniais latinoamericanos, particularmente pelo desenvolvimento da compreensão acerca da colonialidade do poder. Ao realizar uma revisão histórica e estrutural sobre as relações entre indígenas e "europeus" ou "brancos" na região, o autor observa que essas relações foram e são, ainda hoje, pautadas por uma colonialidade do padrão de poder originária da experiência colonial (QUIJANO 2004:77).

Este padrão de poder gerou quatro produtos: 1) a "racialização" das relações entre colonizadores e colonizados; 2) a configuração de um novo sistema de 
exploração da mão de obra e de produção destinada ao mercado capitalista por meio da escravidão dos "índios"; 3 ) a imposição do eurocentrismo como novo modelo de produção e controle do sujeito e 4) o estabelecimento de um novo sistema de controle da autoridade coletiva, fundado na hegemonia do Estado-nação excludente e racista. Para este autor, o "problema indígena" é originário dessa experiência colonial na América Latina. Trata-se de um problema político e um incômodo teórico, que se traduz na colonialidade do padrão de poder e no debate sobre o racismo.

A categoria "índio" só faz sentido em relação a este padrão de poder. No período colonial, o termo serviu para aglutinar diversas identidades particulares que existiam no continente antes da conquista ibérica. Nesse sentido, o "problema indígena" é contemporâneo à fundação das repúblicas ibero-americanas, na medida em que a população "índia" foi percebida como um entrave à implantação do moderno Estado-Nação inspirado pelas ideias da revolução liberal europeia. Desde esse momento, com o "problema indígena" foi constituído um nó "não desfeito até hoje, que ata o movimento histórico na América Latina: o desencontro entre nação, identidade e democracia" (QUIJANO 2004:81).

E no cerne deste desencontro está a questão territorial. Como já havia assinalado Stavenhagen (1979), a terra tem um duplo sentido, por um lado como base estrutural do sistema econômico e força motriz da homogeneização da sociedade. Por outro, é o fundamento basilar dos processos de diferenciação étnica. No confronto entre estes dois sentidos, Stavenhagen reforça a questão racial e justifica sua pertinência ao analisar o processo de estratificação étnica em virtude da hierarquia prevalecente no sistema cultural e no padrão de poder vigente, fundado em concepções racistas.

Para sair deste problema político e teórico, segundo Quijano, é necessário descolonizar as relações de poder, eliminar a exploração e a servidão, além de expurgar a ideia de "raça" como critério de classificação social. Em outras palavras, é necessário desarticular o padrão de poder vigente na região.

A reação à colonialidade do poder pode ser lida através do processo de reorganização do movimento indígena. Essa articulação foi sendo incubada na mesma via de esgotamento do Estado oligárquico, desencadeada com o processo de neoliberalização-globalização da sociedade latino-americana a partir da década de 1970. Em contrapartida à discriminação, ocorreu um processo de re-identificação: de "camponeses" a "índios", depois a "indígenas" e à reclassificação social (da "classe" à "etnia" e às identidades 
regionais e locais). Esse movimento de reafirmação de identidades também ganhou força através da ampliação do universo de comunicação entre os indígenas e o reconhecimento entre si da posição semelhante no interior do sistema "racial" de discriminação e dominação. Esta emergência política é caracterizada pela pluralidade de modo que "não existe, na realidade, um 'movimento indígena', salvo no sentido nominal" (QUIJANO 2004: 91), tendo em vista que a palavra indígena não indica, como o termo "índio", um processo de homogeneização das identidades particulares.

Esse processo de reafirmação de identidades étnicas desdobrou-se na crítica ao sistema de controle da autoridade coletiva. A redefinição do Estado nacional e da democracia política aparece agora como maior desafio em relação ao padrão de poder caracterizado pela colonialidade.

Nina Pacari, advogada, intelectual e ativista política quéchua com papel expressivo no cenário equatoriano, também desenvolve uma análise interessante sobre a emergência do "movimento indígena" e o protagonismo indígena no debate acerca de projetos nacionais. Pacari (2004:41) identifica os mecanismos através dos quais os povos originários da América salvaguardaram e fortaleceram suas identidades e instituições sociais, frente à imposição do novo sistema instaurado pelos colonizadores. De um lado pelo fortalecimento dos usos e costumes na reconstituição dos povos e territórios por parte dos índios, apoiados na recriação da memória ancestral para projetar-se no campo político e social, e de outro, através da apropriação de aberturas externas como os "levantamentos indígenas".

A autora considera três aspectos fundamentais para compreender o "aparecimento" do movimento indígena. Primeiro, a estruturação interna da organização indígena na perspectiva de desenvolvimento da cultura e economia próprias. O segundo aspecto é a reafirmação da identidade, de campesinos às nacionalidades indígenas. Finalmente, no caso do Equador, o controle do mercado agrícola interno, do qual os indígenas juntamente com outros pequenos agricultores respondiam, no início da década de 1990, por $60 \%$ da produção que abastecia o mercado nacional, o que também contribuiu para a consolidação do movimento.

O ponto importante na análise de Pacari é compreensão da diversidade cultural não apenas em uma perspectiva culturalista, mas, sobretudo, questionando a institucionalidade que tange o desenvolvimento dos povos indígenas. Deste ângulo, o problema recai sobre a fundação dos Estados nacionais latino-americanos, mais especificamente sobre o caráter unívoco deste projeto político, que excluiu o princípio da diversidade e da 
pluralidade existentes, que coloca indígenas e negros à margem, em favor de uma racionalidade uninacional.

Por caminhos diversos, esses dois autores convergem para o debate sobre a estrutura de poder dos Estados Nacionais na América Latina. O ponto fundamental para Quijano é a ruptura com o padrão de poder que atravessa a história da região. Pensando no contexto equatoriano, Pacari ressalta que o desafio no século XXI é a construção efetiva de um Estado que seja plurinacional, baseado no princípio da interculturalidade, onde se dê $o$ diálogo entre os diversos setores da sociedade a partir da diversidade que a compõe.

O compromisso político com o destino dos povos indígenas é uma característica historicamente marcante do estilo de etnologia praticado no Brasil (RAMOS, 1990). A preocupação teórica e política com o colonialismo, com a espoliação territorial e com as dinâmicas da identidade étnica tradadas no pensamento social latino-americano também estiveram presentes nos trabalhos de Wagley e Galvão sobre aculturação, nas ideias de Darcy Ribeiro sobre transfigurações étnicas, no modelo da fricção interétnica elaborado por Cardoso de Oliveira e na formulação teóricometodológica de Oliveira Filho para análise de situações históricas e processos de territorialização. Contudo, é curioso notar que não se tenha canalizado esforços para a formalização de uma teoria geral da dominação interétnica ou da colonialidade, ou mesmo uma perspectiva decolonial à brasileira.

Roberto Cardoso de Oliveira talvez seja o autor estratégico para identificar a potencialidade desta aproximação entre estudos sobre relações interétnicas e os trabalhos latino-americanos desenvolvidos na perspectiva decolonial. Para elaborar a noção de fricção interétnica, o autor estabeleceu um diálogo crítico com diferentes variantes teóricas da antropologia americana, britânica e francesa que trataram de relações entre grupos humanos social e culturalmente diferentes, mas também esteve atento ao trabalho de seus colegas latino-americanos.

Um exemplo dessa aproximação é o pequeno ensaio escrito por Cardoso de Oliveira em 1966, intitulado "A noção de colonialismo interno na etnologia" - em que o antropólogo dialoga com os colegas mexicanos, Stavenhagen e Pablo Casanova. Neste pequeno ensaio, Cardoso de Oliveira ressalta o valor da noção de "colonialismo interno" utilizada por Stavenhagen ao indicar como regiões "subdesenvolvidas" no interior dos países latino-americanos funcionavam como colônias subordinadas às estruturas de poder 
controladas por grupos e classes pertencentes aos setores "desenvolvidos" no interior desses países.

Na mesma revista em que Cardoso de Oliveira publicou "Aculturação e Fricção Interétnica", há um artigo do sociólogo Pablo Casanova intitulado "Sociedad Plural, Colonialismo Interno y Desarrollo" no qual ele desenvolveu a ideia de "colonialismo interno" como categoria analítica para explicar sociedades formadas por diferentes segmentos étnicos. Dois pontos são importantes nessa elaboração. Primeiro a questão de escala, Casanova destacava ali o colonialismo não só como um fenômeno presente entre nações, mas também como realidade intranacional. $O$ segundo aspecto seria histórico, já que as condições para a existência do colonialismo interno se deram a partir da descolonização e da emergência das novas nações face aos países colonizadores: "com o desaparecimento direto do domínio dos nativos pelos estrangeiros aparece a noção do domínio e exploração dos nativos pelos nativos." (CARDOSO DE OLIVEIRA 1972:80).

Uma conclusão de Casanova é que o colonialismo permaneceu depois da independência combinando leis de mercado e exclusão de habitantes dessas "regiões subdesenvolvidas" da vida política. Articulando análises psicologistas e valorativas àquelas de tipo estrutural, a noção de colonialismo interno, segundo Cardoso de Oliveira, daria nova amplitude à noção de fricção interétnica. Entretanto, o autor não chegou a desenvolver teoricamente essa "nova amplitude". Cardoso de Oliveira poderia ter enveredado pelo campo da literatura hoje identificada como "decolonial", mas seguiu outro caminho, em diálogo com a filosofia, para pensar a comunicação intercultural, deixando de lado a formalização de uma teoria da dominação interétnica, mas atento à colonialidade da linguagem nos discursos hegemônicos (CARDOSO DE OLIVEIRA 2000).

Para Silva (2015), a desatenção dos estudos sobre contato interétnico à uma teoria da dominação se deveria à baixa consideração à categoria de "raça" como dispositivo ideológico da colonialidade. Olhando retroativamente para a minha experiência de pesquisa entre os Xakriabá, reconheço como os confrontos argumentativos entre "brancos" e "índios" traziam à tona os efeitos da mistura na identidade Xakriabá e resultavam sistematicamente em uma "racialização" dos discursos interétnicos.

Para compreender esse componente racial dessas percepções e discursos, é importante contextualizar historicamente as dinâmicas das fronteiras da colonialidade no norte de Minas e as disputas pela terra são o fio condutor desta história. 


\section{O "problema indígena" no norte de Minas}

As investidas colonizadoras na região do norte de Minas que se têm registro datam de 1640, quando bandeiras anônimas começaram a percorrer o altomédio sanfranciscano (TAUNAY 1948). ${ }^{2}$ Apresento aqui bastante resumidamente essa e as sucessivas ondas de colonização que marcaram a história dessa região. Em 1660, uma dessas bandeiras, capitaneada por Mathias Cardoso de Almeida, fixou-se na região para "aprear" indígenas e exterminar quilombos. A expedição bandeirante teria partido de São Paulo para lutar contra a confederação dos Kariri no Nordeste, quando o lugar serviu de ponto intermediário na operação militar que prosseguiria com a chegada da divisão comandada pelo Coronel João Amaro do Amaral Parente. $^{3}$

Após o retorno do Nordeste, esses bandeirantes combateram grupos indígenas no território sanfranciscano, onde se estabeleceram. Além dos índios Caiapó (VASCONCELOS 1947: 31), os bandeirantes paulistas entraram em conflito com os Chicriabás ou Xicriabás (SAINT-HILAIRE 1975: 340). As fazendas de criação de gado dos integrantes da bandeira de Mathias Cardoso de Almeida localizaram-se "no coração do território Xakriabá, a quem combate e domina, escravizando-os e pondo-os a trabalhar nos preparativos para a instalação de sua fazenda" (PARAÍSO 1987: 19).

Logo, bandeirantes tornaram-se fazendeiros criadores de gado. No início do século XVIII, a administração colonial procurou então impor a esses criadores de gado do norte de Minas a cobrança do quinto, com o objetivo de controlar o sertão do São Francisco e regulamentar o fluxo do ouro amealhado pelo comércio de gêneros alimentícios. ${ }^{4}$ É neste cenário que surge a figura do coronel Januário Cardoso de Almeida, donatário de poderes absolutos de Regente herdados do título de Mestre de Campo concedido a seu pai Mathias Cardoso de Almeida.

\footnotetext{
${ }^{2}$ De acordo com Santos (1997), o rio São Francisco é usualmente subdividido entre seis trechos que correspondem a: baixo - navegável de sua foz a cachoeira de Paulo Afonso; sub-médio - da cachoeira ao porto de Santa Maria de Boa Vista; baixo-médio - entre o porto e a barra do Rio Grande; médio - entre essa barra e a do rio Cariranha, atual limite entre os estados da Bahia e Minas Gerais; o alto-médio - último trecho navegável entre essa barra e o porto de Pirapora e depois o alto trecho do rio entre o porto de Pirapora e suas cabeceiras.

${ }^{3} \mathrm{~A}$ expedição tinha a incumbência de derrotar os grupos indígenas associados sob a liderança dos Kariri em conflito generalizado contra os colonizadores portugueses, conhecido como a guerra dos bárbaros. Diante das conquistas indígenas, os moradores do Ceará requereram o auxílio do Governador Geral e Arcebispo do Brasil, Dom Manuel da Ressurreição, que então, solicitou apoio à Câmara da Vila de São Paulo. Mathias Cardoso de Almeida foi chamado à Vila e, tendo assumido o empreendimento, recebeu, como Mestre de Campo, a tarefa de realizar a campanha contra os índios do Ceará e pacificar o sertão nordestino.

${ }^{4}$ Os bandeirantes paulistas, neste período já transformados em criadores de gado, estabeleceram comércio de gêneros alimentícios com o recôncavo baiano e Salvador. Com a descoberta do ouro, o comércio desses criadores de gado foi transferido para a região aurífera e, devido à dependência de alimentos por parte dos mineradores, uma grande quantidade de ouro foi direcionada para os currais da Bahia, antiga denominação do norte de Minas.
} 
Com a criação da Capitania de Minas Gerais em 1720, os pernambucanos tiveram o limite territorial de sua capitania recuado do Rio Paracatu para o Rio Cariranha e os baianos passaram a ter como marco de fronteira o Rio Verde. Entretanto, no que tange à jurisdição eclesiástica, o sertão sanfranciscano esteve submetido aos Bispados de Olinda e da Bahia até a criação da Diocese de Diamantina em finais do século XIX (ANASTASIA 1983). A fundação de uma missão religiosa pernambucana na região do altomédio São Francisco, teria sido uma tentativa de manutenção dessa região incorporada à capitania de Pernambuco.

Em 1728, Januário Cardoso de Almeida, na qualidade de "deministrador do Índios da Missão do Snr S. João do Riaxo do Itacaramby", ordenou que se juntassem todos os índios que andavam para fora da Missão para que fossem doutrinados e forçados a trabalhar, para que não furtassem os fazendeiros. $\mathrm{O}$ administrador registrou uma carta de doação:

Januário Cardoso de Almeida Brandão deministrador dos Indios da Missão do Snr S. João do Riaxo do Itacaramby Ordena o Cap. [m] Mandante Domingos Dias ajunte todos os índios tantos maxos como feméas $Q$ andarem por fora p[a] ad-missão com zello e cuidado os que forem rebeldes fará prender com cautela para irem para ad-missão Copio e Christão e zello, Mandando-lhe ensinar a Doutrina pellos os $q$ - mais soberem os doutrinatos que vivão bem e se cazem os Mancebados não tendo empedimento ou avendo empedimento fazendo se caze com outro $q$ não tenha empedimento fazendo os trabalhar p[a] terem qi comer e não furtarem e o $q_{-}$for rebelde a esta dutrina que expendo neste papel os prenderá castigará como merecer sua culpa e quando cassar algum ensolente ou levantado fará prendellos e trezellos a $\mathrm{m}$ a prez/çal para lhe dar o castigo conforme merecer porque feito tenho ordem de $q[\mathrm{~m}]$ pode para castigar e prendellos e tirar o abuso de serem bravios e espero do S[n] Cap[m] assim o faca como assim determino e do contrario por ele e pelos mais e isço dei terra com sobra para não andarem pra as fasenda alheia do Riaxo do Itacaramby asima até as cabiceira $s$ e vertente e vertentes e descanco extremando na Cerra Geral para a parte do peruaçú extremando na Boa Vista onde desagua para lá e para cá e por isso deilhe Terra com Ordi de nossa Magestade já assim não podem andarem pelas fasendas alheias incomodando os fazendeiros-missóes para morada o brejo para trabalharem Fora os gerais para suas cassada e meladas. Arraial de 
Morrinhos, 10 de fevereiro de 728 digo 1728. Administrador Januario Cardoso de Almeida Brandão (Certidão VerbumAdverbum - Uma doação - apud OLIVEIRA 2008)

Na visão de Santos (1997), a doação seria resultado de um compromisso entre o poder eclesiástico e o poder local para a constituição de um referendo da autoridade colonial sobre os índios aldeados na Missão. Não existem dados etnográficos referentes à população aldeada em São João no decorrer dos subsequentes anos do século XVIII. O fracasso da Sedição de 1736 - movimento dos grandes potentados do sertão norte mineiro contra as tentativas de controle administrativo por parte da Coroa, que também contou com a participação dos grupos indígenas espalhados pela região contribuiu para que a Missão de São João ficasse destituída de uma referência administrativa, um padre ou mesmo um diretor responsável por longo período.

No início do século XIX, Saint-Hilaire escreve um relato sobre os Chicriabás ou Xicriabás e a construção do aldeamento:

os descendentes daqueles que habitavam essas terras retiravam-se para outros lugares, mas sempre às margens do rio, e edificaram uma aldeia que tem o nome de $S$. João dos Índios. Esses índios fundiram-se com negros e mestiços; todavia, por ocasião de minha viagem, reclamavam do rei o privilégio de serem julgados por um dentre eles, regalia que a lei não concede, creio, senão aos índios puros (SAINT-HILAIRE 1975: 341).

Décadas mais tarde, Richard Burton registrou que, em 1867, São João das Missões ou dos Índios servia de aldeamento para remanescentes de três grandes tribos, "os xavantes (...) os xacriabás (xicriabás) e os botocudos, nome geral indefinido de algumas raças" (1977: 220). ${ }^{5}$

No início do século XX, os índios localizados em São João das Missões eram identificados como "Xakriabá pacificados", antes chamados Gamela, em referência ao botoque labial feito de "gamela", comumente usado pelos integrantes da tribo (PARAÍSO, idem).

A localização geográfica da Missão de São João em uma região de fronteira, distante dos núcleos de poder constituídos da Colônia e do Império - de suas ações de intervenção, administração e controle - contribuiu para a reprodução histórica de uma determinada ordem cultural e uma lógica

${ }^{5}$ As fontes históricas fornecem a impressão de que São João das Missões provavelmente tenha sido habitada por indígenas de diferentes etnias, sendo por essa razão, difícil singularizar a origem étnica de seus habitantes. 
específica de apropriação de terras, regida socialmente por chefes e simbolizada pela doação, a partir da qual os índios de São João organizaram suas relações entre si e com a terra: patrimônio comum e indiviso de todos os índios de São João da Missão. ${ }^{6}$

No ano de 1850 ocorreu um novo ordenamento territorial no país, de acordo com a Lei de Terras. Ocupantes, proprietários ou posseiros passaram a ter que registrar seus terrenos em cartório. Dentro deste horizonte normativo, o patrimônio indígena foi reafirmado nos cartórios de Ouro Preto e Januária em 1856 e assim, confirmou-se o Termo de Doação de 1728, assinado por Januário Cardoso de Almeida.

Entre o final do século XIX e início do século XX, a composição social da região foi sendo transformada. Um número expressivo de famílias oriundas do Estado da Bahia veio fixar-se ao redor de São João das Missões, estabelecendo relações de casamento e compadrio com a população nativa.

No final dos anos 1950, o governo de Minas Gerais deu início a um processo de regularização de terras consideradas devolutas em todo o Estado. No início da década seguinte, o plano estadual de colonização agrícola identificava um grande volume de terras enquadradas como propriedade do Estado no norte de Minas, nas terras da Jaíba e nas planícies do cerrado, que incluíam todo o vale à esquerda do alto-médio São Francisco.

Para realizar a regularização fundiária, foi criada a Fundação Rural Mineira - Colonização e Desenvolvimento Agrário - RURALMINAS, em 1966. Essa agência ficou encarregada de representar o Estado na discriminação dessas terras devolutas, na legitimação da propriedade, uso e reintegração de posse. A RURALMINAS passou a intervir na área dos Xakriabá em algum momento entre os anos 1967 e 1969, cobrando dos moradores, na qualidade de "posseiros", uma taxa de ocupação de terras devolutas e à adesão ao plano, cuja quitação de prestações anuais lhes garantiria o direito ao título de propriedade dos terrenos ocupados pelos mesmos.

Essa intervenção da RURALMINAS instaurou uma crise social. A proposta de regularização desestabilizou o sistema de posse e controle da terra entre os vários grupos familiares e desencadeou um processo de mobilização de lealdades políticas e morais a partir dos laços de parentesco, que resultaram no movimento de algumas lideranças locais no sentido de reagir à pressão

\footnotetext{
${ }^{6}$ Patrimônio comum e indiviso, usufruído pelos índios e seus sucessores em um sistema de posse comum, em que o controle da terra é exercido como define Almeida: "através de normas específicas (...) instituídas e acatadas, de maneira consensual, nos meandros das relações sociais estabelecidas entre vários grupos familiares de pequenos produtores diretos" (ALMEIDA1987:43. Apud. SANTOS 1997).
} 
do governo estadual, entre elas, a realização de viagens à Brasília em busca de alguma providência por parte do governo federal. ${ }^{7}$

Manuel Gomes de Oliveira (conhecido como Rodrigo) realizou diversas viagens à capital que resultaram na inserção da Fundação Nacional do Índio (FUNAI) no problema da terra. ${ }^{8}$ Logo, o problema da identidade indígena do grupo passou a interpor o processo de regularização fundiária. Lidando com a lógica de identificação baseada critérios de indianidade colocados em jogo pela FUNAI, os grupos familiares que se afirmavam como "índios" iniciaram um intenso processo de reelaboração cultural. Os Xakriabá elegeram Rodrigo cacique, que deixou o cabelo crescer e teve início uma revitalização do universo simbólico indígena a partir da memória dos mais antigos, identificação de vestígios de costumes religiosos e da cultura material, além de revelações mágico-religiosas que seriam acionadas como demarcadores da diferença. Tais elementos, uma vez formalizados, passaram a cumprir a função política de legitimar a indianidade dos Xakriabá fundada pelos troncos antigos. ${ }^{9}$

Nas décadas de 1970 e 80 as atuações da RURALMINAS e FUNAI contribuíram para que uma situação de incerteza perdurasse e fosse aumentando no transcorrer dos anos. Um quadro contraditório no plano institucional e tensa no plano local, marcada por violências e intimidações, por alianças e clivagens, invasões e retomadas de terra, e, crucialmente por assassinatos de índios.

A década de 1980 é lembrada como a época das retomadas das terras pelos Xakriabá. Nesse período Rosalino Gomes de Oliveira surge como liderança fundamental na organização das ações indígenas no plano local. Através dos chamados mutirões, os Xakriabá começaram a realizar o processo de

\footnotetext{
${ }^{7}$ João Pacheco de Oliveira Filho (1998) identifica em vários estudos realizados sobre grupos étnicos do Nordeste, a atuação decisiva de lideranças, que de certa forma, tornaram-se emblemáticas. Entre os casos: a atuação de Acilon entre os Turká, de Perna-de-Pau entre os Tapeba e de João-Cabeça-de-Pena entre os Kambiwá. Em suas viagens às capitais do Nordeste e ao Rio de Janeiro, em busca do reconhecimento do S.P.I e da defesa das terras ocupadas por seus grupos, essas lideranças desencadearam processos sociais que implicaram à instituição de mecanismos de representação, o estabelecimento de alianças externas, a elaboração de projetos de futuro e a unificação de interesses dispersos que Oliveira Filho analisa a partir da metáfora da viagem da volta (1998:23).

${ }^{8}$ Em 1966 uma inspeção do Serviço de Proteção ao Índio - (S.P.I), com a finalidade de "inspeccionar(sic) as terras dos índios 'GAMELAS'..." o relator afirmava que "...a situação social dominante na região, criada por invasores $e$ posseiros,(...) fugia da alçada do S.P.I, a solução dos problemas decorrentes..." (FUNAI 1969. Apud. SANTOS 1994:10/1997:72). Em virtude da conclusão da inexistência de "índios de primeira categoria" na região. A posição do relator fundamentou-se nas observações quanto à ausência de organização tribal, de religião e idioma próprios, conforme consta no relatório de viagem a São João das Missões.

${ }^{9} \mathrm{O}$ termo "troncos antigos" recebe em outras áreas e situações no nordeste do Brasil variações como: "tronco velho", "ponta de rama", "raiz do pau". Essa semiotização do mundo natural, nesse caso da flora, transformada em cultura, pode ser interpretada segundo Barretto Filho (1994) como expressão de uma certa concepção do tempo e das relações - de continuidade e de descontinuidade - entre as gerações, atualizando certos princípios de classificação. No caso dos Xakriabá, de uma continuidade entre antigos e contemporâneos.
} 
desocupação de suas terras e a adesão ou não à luta passou a ser o elemento decisivo na reformulação das fronteiras entre os grupos sociais em conflito.

Esse foi um período violento, marcado por intimidações, espancamentos, invasões e destruição de cercas. Os embates culminaram em um evento trágico: os assassinatos de Rosalino Gomes de Oliveira, Manuel Fiuza da Silva e José Pereira Santana. Os crimes ganharam repercussão nacional, sendo enquadrados como genocídio e levados à júri federal. $O$ fazendeiro Francisco Assis Amaro, mandante dos crimes, foi preso poucos dias depois, juntamente com alguns dos executores da ação. O julgamento dos assassinos causou uma ampla mobilização de diversos setores da sociedade, como políticos, Igreja, ONGs e lideranças indígenas de todo o país, que buscavam a punição dos culpados e o reconhecimento definitivo da indianidade Xakriabá e do seu direito sobre a terra.

Diante deste acontecimento trágico e de sua repercussão, a FUNAI realizou a retirada dos posseiros da área, em menos de dois meses após a morte de Rosalino. A Terra Indígena Xakriabá foi homologada logo em seguida através do Decreto Presidencial número 94608, publicado no Diário Oficial da União, em 14 de julho de 1987.

A partir deste breve resumo do processo histórico das ondas de colonização e das disputas territoriais, imagino que seja possível imaginar a dinâmica das relações interétnicas na região. Depois de uma longa e violenta batalha pelos direitos territoriais, os Xakriabá fortaleceram sua organização social e a identidade passou a representar não só um movimento de resistência ao colonialismo interno, mas também um projeto de transformação das estruturas locais de poder.

\section{Mudanças no padrão de poder entre índios e brancos em São João das Missões}

Os "brancos", ou "não índios" de São João das Missões constituem a parcela regional com a qual os Xakriabá convivem de forma mais próxima, no desenvolvimento de atividades produtivas, através das relações comerciais, mas também pelas alianças e disputas políticas em torno do poder administrativo do município - emancipado em 1995.

Antes da emancipação de São João das Missões, a reserva e o povo Xakriabá estiveram associados, do ponto de vista político-administrativo, ao município de Itacarambi. No decorrer da década de 1990, Rodrigo foi eleito para a Câmara Municipal deste município. A relação dos Xakriabá com a esfera de poder municipal foi marcada pela oposição ideológica e pelo clientelismo. Por um lado, o conflito fundiário, que alcançou seu ponto 
crítico na década de 1980, colocou os indígenas em oposição direta com a maior liderança política local, José Ferreira de Paula, prefeito de Itacarambi. Por outro, deve-se considerar o fato dos Xakriabá constituíremse como uma notória parcela do eleitorado do município, o que lhes conferia uma força política significativa nas disputas eleitorais.

Com a criação do município de São João das Missões, os Xakriabá converteram-se em força política decisiva na disputa pelo governo local. Os Xakriabá elegeram o cacique Rodrigo vice-prefeito por dois mandatos. Junto com ele, também foram eleitos dois vereadores para Câmara Municipal, sendo um deles Zé de Rodrigo, filho do cacique geral.

O cacique e vice-prefeito Rodrigo faleceu em abril de 2003, vítima de complicações cardiovasculares. Sua ausência gerou reflexos importantes na organização social interna do povo Xakriabá e, consequentemente, no campo político intersocietário. Em meio ao contexto do falecimento de Rodrigo e ao processo de sucessão do cacique, foram erigidas novas formas de organização e de distribuição do poder interno diretamente relacionadas às estratégias frente ao modelo tutelar e às diversas instituições e instâncias estatais.

As lideranças indígenas passaram a percorrer os meandros do aparelhamento estatal de forma cada vez mais organizada, com a estruturação do movimento em associações, comissões e conselhos específicos para a saúde, educação e meio ambiente. Nesse sentido, as perspectivas dos indígenas habitantes da terra indígena demarcada face às relações políticas e eleições municipais de São João das Missões vieram sendo progressivamente reelaboradas. Essa reafirmação política da identidade indígena se expandiu.

Paralelamente, no início do ano de 2004, teve início um movimento de conscientização étnica e a mobilização social de famílias residentes na periferia do município. Esse grupo passou a reivindicar parte do território indígena delimitado no documento de doação expedido em 1728 e deixado de fora nos dois processos de demarcação de terra realizados pelo governo federal na região em 1987 e 2003. Esse movimento de etnogênese secundária de aproximadamente 40 famílias de Xakriabá "desaldeados" provocou a reação de diversos moradores não indígenas mais antigos da região.

É neste contexto que ocorreu a discussão que textualizo a seguir. $O$ acontecimento poderia ter sido apenas mais uma situação cotidiana de relações comerciais entre um "índio" e um "branco" em São João das Missões. O primeiro, se dirigiu a uma pequena mercearia pertencente ao 
segundo, localizada no entorno da praça central da cidade, para adquirir gêneros alimentícios. Contudo, esse encontro transformou-se em um momento de interpelação à indianidade do lavrador Xakriabá, reveladora da racialidade do sistema interétnico, mas também de expressão da força política e emocional da etnicidade.

\section{Xakriabá interpelado}

Do lado de dentro do balcão, Seu Antônio Maria, comerciante e pequeno produtor de São João das Missões e filho de uma família com longa tradição no domínio de terras no entorno do município. De outro, João, morador da zona rural do município, onde trabalhava de forma arrendada na terra de fazendeiros. João também era integrante do movimento recém iniciado à época. Esse grupo, liderado pelo cacique Santo Xakriabá, começou a sua articulação com o apoio do Conselho Indigenista Missionário - CIMI. O objetivo era o de buscar o direito territorial, reivindicando a demarcação de uma nova área indígena e a ampliação do território Xakriabá. Depois de alguns minutos de diálogo entre mim e Seu Antônio Maria, João entrou no comércio e, ao tomar conhecimento do assunto, interferiu na conversa.

Antônio Maria: Ele está fazendo uma gravação do pessoal. Fala aí.. do pessoal que tem mais conhecimento sobre a área indigena, sobre aqui, sobre o movimento, sobre as brigas. Expliquei para ele direitinho, como é que foi a situação aqui. $A$ situação aqui é como se diz... graças a Deus está em paz, não é? João, que o que está ocorrendo é que ninguém aqui em Missões hoje, só do povo que mora aqui dentro, o pessoal não dorme, assim, tranquilo porque, aquela proposição toda hora de tomar, não é? "Eles vão tomar!" Tudo que se fala em Missões é que eles só falam de tomar Missões, não é? "Missões, o município de Missões vai ser tomado! Os índios vão tomar conta!". E o povo fica todo doido de cabeça! Então fica assim, o povo não tem paz...

João: Eu me coloquei naquele patrimônio indígena, porque foram os índios que primeiro habitaram, aqui dentro de Missões. Aqui foi, os primeiros índios habitaram aqui dentro. $E$ uai! Aqui tem um exemplo, a avó do meu pai. A avó do meu pai foi pega onde? Foi aqui dentro, vaqueiro que foi apiando, pegou ela menininha, aqui dentro.

Antônio Maria: Até no Fabião! Até no Peruaçu diziam que era deles. Mas isso é conversa porque eu não vi escrito. Eles não 
vão lutar lá contra um município grande como Itacarambi. Eles vão ter que tentar onde tem cinco mil pessoas, quatro mil pessoas que é Missão, São João das Missões. Antes era cinqüenta e cinco mil hectares que eles tinham. Depois, foi não sei quantos mais mil hectares. Eles ficaram com quase noventa mil hectares de terra aí! E ninguém mora! Na metade ninguém mora, é mata e vaca.

João: Ô Antônio, a área primeira está interditada. Essa área daqui é uma área pequena. Agora só que tem um detalhe, tem mais quarenta famílias que estão lutando por mais... como diz? O restante que ficou pelo lado de fora. Eu conheço a área, nasci e criei dentro nessa área. Qual é a parte que tem aí, que se inclui a família de lá para dentro? [...]

Antônio Maria: É porque o pai dele pegou a terra todinha e vendeu. Eu sou testemunha que a terra do pai dele, todinha, foi pega e vendida. Como é que ele quer voltar lá para dentro?

João: É verdade. Hoje eu tenho uma casa aqui, suado, derramado o suor. Não herança dos meus pais. Ficou uma casa, uma casinha, está caindo os pedaços lá. [...]

Eu não estou querendo a que meu pai vendeu. Eu quero o direito que me assiste. Direito dos índios nunca acaba! Para isso foi aprovada uma lei, você não sabe, eu sei disso aí. Essa é a mesma situação de todos que estão aqui dentro, todos, conheço um por um. Ô Antônio, sabe o quê que acontece? Às vezes éo seguinte, vocês põem na cabeça que nós estamos procurando terra que não são nossas. Não, você sabe que terra indígena já diz. Esse direito ninguém tira.

Antônio Maria: Mas o Brasil todo é indígena moço! O Brasil todo não é indígena? Então, se já foi determinado as áreas indígenas, ninguém pode entrar lá dentro. E daqui mais alguns dias tem duzentos e cinquenta famílias lá em Itacarambi. Essas que ele falou lá, lá são duzentas e tantas famílias que quer também terra, vão recorrer lá para querer mais terra dos índios. Vai ter que indenizar o município de Itacarambi todo então!

João: Ô Antônio, um homem que nasceu na roça, criou na roça, não tem profissão, não tem estudo, ele tem que viver onde? $\mathrm{Na}$ roça! Eu vou viver de que? 
Antônio Maria: Como é que o governo vai querer tirar uma cidade dessa aqui, tirar a população?

João: Você está doido da cabeça! Não tem necessidade.

Antônio Maria: Pois é. Mas se ele resolver indenizar o município aqui? O pessoal na cidade vai viver de que? Se não tem serviço não tem nada. O que tem é a área que o pessoal trabalha, que essas quatro mil famílias que tem em Missões aqui, vive aqui do município. As roças são daí e se amanhã for indenizado, o município aqui, Missões, vai viver de que?

João: Continua vivendo do que sobrevive o município, Uai! Continua.

Antônio Maria: Mas se nós não podemos trabalhar lá? Por que hoje eu provo para você que eu tenho cinco, seis, hectares de arroz plantado lá. Ele dá serviço para quantas pessoas? Agora nós estamos todo mundo lá trabalhando, amanhã eu não vou lá trabalhar mais, eu não posso. Eu vou ter que sair daqui. Não é todo mundo que está apossado há setenta anos, oitenta anos, como eu estou apossado nessa terra lá. Meu pai tem 80 anos, eu tenho 54 anos. A pessoa tem o seu direito de usucapião, ué?! É a mesma coisa que o índio.

Porque se você for analisar, o Brasil inteiro é indígena! Se o governo marcou a área indígena é lá, não é você querer aumentar mais, não tem condições. Você vai aumentando, aumentando, para onde? E daqui a pouco vai perturbar o povo, uai! Vai ter que dar terra onde não tem. Porque todo mundo sabe que o pobre vive da roça.

João: Eu só digo para você o seguinte, eu não posso dizer que é só Santo que está nessa luta porque eu também estou. Apesar de que eu nem queria entrar, mas ele me chamou: "João você nasceu e criou na área, você não pode dizer assim "eu não sou índio". Eu sou índio! Eu sou descendente indígena $e$ desaldeado.

Antônio Maria: Eles arrumaram gente de todo jeito aí para dar terra! É assim que fizeram esses desaldeados! Foram pessoas que agora eles estão catando. Estão procurando mais, para aumentar mais a ficha lá, de pessoas, para poder querer ter 0 resto do município. Mais eu falo: e a população daqui? Vai para onde? Tem jeito de conviver numa vida dessas? Não existe isso 
não, uai! Você não dorme mais tranquilo, o espírito de ninguém funciona certo não.

João: Eu só digo assim. Nasci foi aqui, criei foi aqui. Tem meus filhos para poder criar. É por aqui. Ô Antônio, minha mãe você conhece, nasceu na área indígena, a minha sogra nasceu lá na área indígena, tudo é lá na área indígena! Nascido e criado até a descendência do meu avô está lá dentro.

Nós vamos ver lá atrás quem foi que foi o direito gerado primeiro. Não foi o direito dos índios? Foi! A coisa é tão justa. Um exemplo, quando um índio tem origem da terra, ele tem origem de índio, sabe que ele tem documentação que ele nasceu e criou ali. Ele não procura mexer direto com os fazendeiros: olha meu direito de minha terra é aqui eu vou viver aqui dentro. Ele procura os direito aonde? Lááááa!!!!!!! Onde estão trancados os direitos dele. Ele procura lá. O governo é que vai negociar com os fazendeiros, negociar tudo. A justiça é que vai lutar quando entregar nas mãos, cada qual indenizada. Aí nós vamos receber a terra. Nós não vamos atrás, diretamente. Só que o nosso direito, nós vamos atrás dele desde de 1729! Nem eu sabia. Mas agora eu estou por dentro. Só que, quando foi a primeira área que foi demarcada aqui, já existia o direito nosso aqui.

Antônio Maria: Vocês têm escritura disso? Marcado tudo?

João: Tem Antônio, tem! Eu te falo para você que tem um documento feito aqui, de 1729! Eu não recordo agora quem foi o primeiro que lançou isso aqui, mas... Mathias Cardoso... Mathias Cardoso... Inclusive houve matança de indio aqui nessa área, houve matança de índio aqui. Foi Antônio, aqui dentro de Missões. Essa aqui foi a primeira área de índio habitada aqui dentro.

Antônio Maria: Eu nunca ouvi falar nisso.

João: Eu te falo, para você, e provo! Porque nem eu sabia disso aqui, mas hoje eu sei. Vamos, como é que você adquiriu isso aí? Vamos lá em Brasilia, vamos procurar lá dentro, o direito lá dentro onde é que eles estão.

Antônio Maria: Mas demarcou já o local, já está demarcado e eles tão querendo aumentar. Eles não querem parar mais de aumentar. Mais esse debate é muito bom para eles lá (aponta 
para mim querendo dizer de estudiosos). Você sabe o que os outros estão querendo, não é? Ás vezes eu sou proprietário, não é? Aí eles analisam direitinho, não é? Agora eu não. Eu não sou contra, como eu falei para você, se me pagar amanhã mesmo tchau e benção. Eu vou embora lá para Montes Claros, para um lugar melhor do que eles estão querendo. Mas eu tenho que ser indenizado porque eu não posso deixar um trem desse aqui, porque eu vivo, é aqui.

João: Se durar cinquenta anos, daqui cinquenta anos se eu não existir meus filhos existem, acontece que existem os meus netos e por aí vai. Um exemplo que passa de geração em geração. Eu não vou desistir não!

Antônio Maria: Se eu nasci foi aqui, eu vou correr daqui para onde? Só que tem um detalhe, se sair a propriedade dele, amanhã você já falou para mim que vai morar em Januária. Amanhã ele nem está mais aqui! (risos)

João: Januária! De jeito nenhum! Ô Antônio, se eu quisesse morar em Januária, eu não estava lutando para volta para onde eu nasci. Eu nasci foi aqui. Minha esposa é de lá, mas ela está é aqui e eu vou tirar meus filhos daqui para sofrer em outra cidade? Eles vão formar. Claro! Eles estão estudando, eles vão formar e eu vou viver de que? Para a roça vou eu, e meus filhos continuam estudando.

Antônio Maria: Eu conheço o seu, você trabalha arrendado.

João: Não. Porque eu trabalho arrendado também. Arrendado... Eu tenho um lote. Eu posso dizer que eu tenho terra? Não dá nem hectare, eu tenho terra nenhuma!

Antônio Maria: Essa é uma polêmica muito difícil, é complicadíssima!

João: É nada.

Antônio Maria: A mais difícil que tem é essa área indígena. Se você pegar o código do índio e ler, que eu já vi lendo, Nossa Senhora! É uma... não é?

João: Eu que digo para você. O direito nosso ninguém tira! Não adianta ó... fazendeiro... ninguém tira. 
Antônio Maria: Mas, olha, eu estou falando aqui. Como eu falei para ele (dirigindo-se a mim) que aqui não tem mais índio e está na cara. Pode vir aí e fazer uma análise. Tem descendente. Descendente é só a aparência de índio, aí tem mais ou menos umas oito ou dez, quinze famílias que têm ainda assim a vista, o jeito, a tendência, como o velho Rodrigo mesmo que era $o$ cacique tinha a tendência. Mas se você olhar para esse menino aqui, ele não tem a tendência de índio.

João: Ô Toim, por exemplo, você sabe quem era o finado Rodrigo? O pai do finado Rodrigo era irmão do pai do meu pai, o quê você acha que ele é? Ele era primo carnal meu, moço.

Antônio Maria: Eu falo. É olhar João. É você chegar e olhar e ver a pessoa e falar assim: "uai!' Mas, isso aí, você já está no homem branco já".

João: Não, eu não sou homem branco! Eu não sou homem branco! Eu sou índio e acabou! Sou índio e acabou!

Antônio Maria: Será índio do cabelo duro? O índio tem o cabelo bom... eu também. Se eu quisesse um pedaço de terra aí, uma fazenda, eu ia passar também que nem índio, eu nasci e criei aqui.

João: Eu não quero fazenda, Toim! Não sou fazendeiro! Eu quero um lugar meu para trabalhar.

Antônio Maria: Eu nasci e criei aqui dentro. Então eu poderia também assinar lá o papel que eles fizeram, dos desaldeados. $E$ eu, também, tenho direito. Então, o que eu tinha que fazer? Querer também um direito de terra lá, porque se todos têm direito, eu também tenho. Eu sou índio, eu nasci e criei aqui dentro.

João: Ô Toim, olha só, tem um detalhe nem você está sabendo o que é. Você nasceu e criou aqui, você não pode discutir, dizer que eu sou branco. No caso seu, você está escondendo a sua origem. Eu não escondo a minha. Aqui dentro de Missões, se for preciso até lá dentro de Brasília falar, o que você é? "Sou Xakriabá, nascido e criado dentro da área indígena!".

Antônio Maria: Mas se chegar lá na demarcação, você está por fora, seu pai está por fora. 
João: Estou lá dentro! Nós somos cadastrados indígenas. Não adianta, Toim. Essa parte aí é muito sublime, é uma parte que depende de muita coisa, essa parte aí não adianta discutir com você, não adianta.

Antônio Maria: Isso aí para mim é um prazer você ser premiado. Todo mundo aqui tem sua propriedadezinha e se eles ganham essa área de terra que eles estão querendo aí, essas fazendas aí. Vão sorrir com a miséria dos outros.

João: Eu só falo para você o seguinte, até o último minuto da minha vida, se depender de mim eu estou junto com ele (Santo). Eu tenho que pensar em mim, na minha família e em muitas famílias que estão dependendo disso aqui. Agora eu vou desconsiderar o meu lugar? Vou desconsiderar as pessoas que moram aqui? Não. Agora, aqueles que quiserem pedir, vamos pedir juntos, os direitos são iguais! Agora, só que tem um detalhe, deixando em ambas as partes o nosso direito, a nossa sobrevivência. Porque eu não estou assim. Ah... eu quero terra, justamente eu tenho que ver lá no futuro. Meus filhos vão para onde? Eles vão viver na cidade, virar bandido, marginal? Se aqui não tem serviço, a gente tem que partir para onde? Para a roça. Lá eu tenho. Eu vou viver é do milho, é do feijão, é do que a terra produz. Terra de fazendeiro não é terra minha, o que acontece é que na terra do fazendeiro eu não posso plantar um pé de laranja. Não posso plantar uma moita de cana. Não posso plantar, não posso plantar nada. Fazendeiro derruba um pedaço de terra, um exemplo, esse ano ele quer o capim, ele tem o gado, lógico ele vai querer o lado dele. Eu quero o quê? Eu quero o milho, o feijão, a mandioca, o que a terra produzir, isso aí eu quero. (São João das Missões, janeiro, 2004)

\section{Indianidade, mistura e reflexos políticos.}

Revendo esse encontro etnográfico à luz dos diálogos teóricos do pensamento social latino-americano sobre a "colonialidade do poder" e o "problema indígena" e suas intersecções com as imagens da mistura e da fronteira presentes na historiografia e nos discursos locais, considero importante destacar dois pontos. 0 primeiro é o problema dos sentidos da terra, de onde é possível explorar a dimensão territorial e étnica da fronteira. O segundo é questão da identidade, que revela dimensões biológicas, culturais e políticas através das imagens da mistura evocadas no diálogo e pelos reflexos do movimento indígena no cenário político local. 
Para tratar do problema territorial é importante recuperar as ideias de Stavenhagen (1979) sobre a terra como fator estrutural e força motriz da homogeneização da sociedade. O processo de regularização fundiária realizado na região foi empreendido sob essa premissa. É importante destacar a posição de João (e da maioria das famílias do grupo ao qual pertence) na estrutura do sistema produtivo local. $O$ trabalho na modalidade do arrendamento retira dos indígenas qualquer possibilidade da autonomia territorial. Nestas condições, o processo identitário pode ser lido como um projeto de transformação da realidade colocado em curso por atores sociais que, utilizando-se de material cultural ao seu alcance, procuram erigir uma "nova identidade", capaz de redefinir suas posições sociais na estrutura social mais ampla (CASTELLS,1999).

Essa dinâmica identitária expressa o caráter histórico e processual da fronteira (NUGENT 1998). Destaco aqui três momentos históricos em que o estabelecimento da fronteira territorial se reveste por projetos e interesses distintos. Em um primeiro momento, quando da doação de terra aos índios da Missão de São João realizada por Januário Cardoso de Almeida em 1728, - estabelecimento da fronteira teve um caráter eminentemente civilizatório, perceptível nos termos do documento que prevê a definição dos limites territoriais e as incumbências de catequizar os índios e fazê-los trabalhadores.

O relato de Saint-Hilaire (1975), datado do início do século XIX, já informava sobre mistura entre índios, negros e mestiços no aldeamento de São João das Missões. Neste sentido, as informações históricas indicam a presença de grupos culturalmente diferentes, não necessariamente constituídos como uma unidade social coesa e indivisa através do tempo.

O segundo momento o caráter da fronteira passou de civilizatória à socioeconômica, quando o projeto de expansão da fronteira agrícola colocado em prática pelo governo estadual enquadro as terras como devolutas e passou a cobrar o pagamento de títulos e taxas para a regularização da posse. Esse contexto desencadeou o processo de reelaboração cultural, de revisão da história e redefinição da fronteira étnica.

O terceiro momento, mais recente, é marcado pela afirmação da identidade, de fortalecimento e protagonismo do movimento indígena através da conscientização étnica e da mobilização social. É possível observar nesse momento como as representações nativas da realidade apropriam-se e transformam a linguagem oficial mediante as circunstâncias da 
experiência particular da fronteira vivenciada por indígenas e "brancos" em São João das Missões.

Antônio Maria e João argumentam diferentes leituras sobre a história local e sobre os reflexos dos direitos indígenas garantidos constitucionalmente desde 1988 no Brasil. Enquanto Antônio Maria revela horror ao Estatuto do Índio e afirma seu direito como pequeno produtor e de posse da terra pela usucapião, João questiona o princípio do direito quando interroga: "Nós vamos ver lá atrás quem foi que foi o direito gerado primeiro. Não foi o direito dos índios?"

Comparando as informações históricas e o discurso de João é possível perceber como, bem informado, despertou-se nele a consciência de uma territorialidade ancestral, e de como a questão da fronteira, tanto territorial como étnica, podem variar historicamente em São João das Missões, uma vez que a terra indígena demarcada ainda é bem menor que os limites outorgados pelo documento de doação. Nada impede que outros grupos familiares venham a aderir ao movimento étnico como instrumento de transformação de suas posições na estrutura social.

Vários trabalhos que tratam sobre o atual "movimento indígena" na América Latina procuram refazer um balanço dos impactos da conquista sobre as sociedades que ocupavam originalmente o continente, com ênfase nas relações entre cultura e política que marcam os processos identitários e a presença indígena na esfera pública contemporânea. Quijano (2004:77) aponta que o atual "movimento indígena" é o sinal proeminente da crise da colonialidade do poder instituída desde a conquista. Nessa direção, Pacari destaca o protagonismo indígena na refundação dos Estados nacionais na região.

O contexto político em São João das Missões apresenta um exemplo local desta crise, na medida em que o movimento indígena conquista espaços na esfera pública local, ao mesmo tempo em que a identidade opera como instrumento político eficaz na busca de direitos.

Diante da crise das estruturas estabelecidas, a imagem da mistura parece qualificar a gramática das representações regionais face à indianidade Xakriabá, como uma estratégia para deslegitimar o movimento. Isso fica evidente em passagens como essa: que aqui não tem mais índio e está na cara. É você chegar e olhar. Ver a pessoa e falar assim: uail! Mas, isso aí, você está no homem branco já. De onde se depreende que, contraposta à imagem romântica e genérica do índio em seu viés biológico e racial: cabelos lisos, olhos puxados, pele avermelhada, a imagem de um Xakriabá apresenta um tipo de gente que ultrapassaria o limite prescrito desta indianidade, sendo, 
impossível distingui-los do homem branco. A racialidade das concepções envolvidas nas relações interétnicas aparece como argumento.

A indianidade Xakriabá e as fronteiras geopolíticas e jurídicas que os separam dos não índios são vistas regionalmente mais como fruto de uma violência simbólica por parte do Estado, produtor de taxonomias sociais e emissor legítimo da imposição que consiste a nomeação oficial (BOURDIEU 1998), e não uma identidade reconhecida historicamente nas relações territoriais. Como comentava Seu Antônio antes da chegada de João, "São descendentes, não índios mesmos, com descendência. Mas, o governo registrou como índio tem que ser índio acabou!"

A disputa sobre os sentidos da identidade indígena é indissociável das tensões dentro de uma hierarquia social e seus interesses diversos como a posse da terra, os recursos sociais, o poder político e a condução dos destinos do município. Um "índio" ocupando a posição de prefeito representaria a inversão desta estrutura, passando alguém do polo inferior para o polo superior. Uma crise da colonialidade, um movimento impensável na lógica da ideologia racial brasileira.

O processo de reafirmação da identidade Xakriabá como indígena trouxelhes a possibilidade de reelaborar as concepções de si mesmos como sujeitos de direitos históricos e também quanto às relações do grupo com seu passado e sua origem. Além disso, lhes trouxe a oportunidade da ampliação dos seus horizontes de experiências e percepções, colocando-os em relação com os "parentes" de outros povos indígenas, diversas instâncias e instituições sociais para além do campo político regional.

Nesse processo, percebe-se a progressiva conquista de um conjunto de direitos específicos, como a saúde e educação diferenciadas. Direitos que são interpretados como privilégios pela população não índia, principalmente de São João das Missões e que alimentam as tensões e o conflito.

É interessante observar que, se por um lado, setores da sociedade regional colocam em dúvida a legitimidade da identidade, algumas vezes com veemência, outras apenas com jocosidade. Por outro, a descendência indígena é amplamente reconhecida, como pode ser lido nas categorias usadas como referentes de atribuição aos mesmos: sejam descendentes e/ou remanescentes de índios.

Durante muito tempo os Xakriabá foram reconhecidos regionalmente como "caboclos". As referências aos "caboclos", seja para definição da terra ou de seus habitantes, aparecem como categorias representativas da percepção 
regional da mistura em termos culturais e da ideia do caboclo como uma identidade transitiva entre o "índio" e o "branco". Se por um lado, a referência funciona como negação da existência dos Xakriabá como índios mesmo, por outro, reforça a fronteira e a distância entre estes e os outros segmentos regionais.

Já no quadro de valores indígenas contemporâneos, a descendência é o elo fundamental entre o sentimento de pertencimento étnico e ao lugar de origem. A ancestralidade é reelaborada de tal forma que a mistura não dissolve o laço que lhe é anterior.

Enquanto o vocabulário e argumentação pós-modernos trabalham com as noções de "hibridação" e "mistura" como sinal dos tempos (GRUZINSKI 2000) e identidades compósitas por oposição a identidades atávicas (GLISSANT 2005), a etnicidade Xakriabá - essa retórica cujo teor invoca uma origem e uma cultura comuns (CARNEIRO DA CUNHA 1987) - presente na fala de João parece caminhar em uma direção contrária, refazendo conexões essenciais com determinadas concepções de origem. De certa forma, o discurso de João sintetiza uma elaboração mais ampla dos Xakriabá. Os comentários de João Pacheco contribuem para compreender a questão:

A etnicidade supõe, necessariamente, uma trajetória (que é histórica e determinada por vários fatores) e uma origem (que é uma experiência primária, individual, mas que também está traduzida em saberes e narrativas aos quais vem acoplar). 0 que seria próprio das identidades étnicas é que nelas a atualização histórica não anula o sentimento de referência à origem, mas até mesmo o reforça. É da resolução simbólica $e$ coletiva dessa contradição que decorre a força política $e$ emocional da etnicidade (OLIVEIRA FILHO 1998: 64).

No argumento de Antônio Maria, a mistura tem um significado estritamente biológico ou racial, como fica claro em diversas passagens: (...) o velho Rodrigo mesmo que era o cacique tinha a tendência. Mas se você olhar para esse menino aqui, ele não tem a tendência de índio. Será índio do cabelo duro? O índio tem o cabelo bom... eu também.

Já do ponto de vista de João, se Rodrigo aparece face à sociedade regional como a representação ideal daquele que possa ser de fato, considerado índio, a relação irrevogável de parentesco com o cacique, carnal nas palavras de João, permite entrever que para os índios, os sentidos da consanguinidade transcendem as contradições da mistura em sua dimensão racial biologizante do imaginário nacional. 
Há um deslizamento para um outro patamar, que se resolve de forma "muito sublime", na qual o sentimento de pertencimento étnico é indissociável do pertencimento à terra. Ter "nascido" ali estabelece um vínculo primário, transmitido biologicamente, entre João e a coletividade maior, metaforicamente fundada nos troncos antigos. Ter sido "criado" ali propicia a partilha do vínculo sociocultural com os mesmos, que se traduz na defesa do direito pensado como comum e originário.

As contingências históricas não fizeram distanciar os Xakriabá, os "desaldeados" e João de suas origens. Não comprometeram a intensidade emocional e a força política que caracterizam a afirmação da sua identidade étnica. É da resolução nativa desta contradição entre uma cultura originalmente diferente e as circunstancias históricas frente às estruturas coloniais, juntamente com a abertura do campo político contemporâneo à possibilidade da descolonização deste padrão de poder hierarquizado racialmente que a afirmação identitária revela sua força.

Nesse sentido, a identidade é uma resposta política e cultural, estratégia e prática social cotidiana na busca de melhores condições de vida, de alternativa à sujeição econômica através da conquista de um lugar. Mais que uma propriedade, o direito territorial sintetiza outras dimensões da vida, tais como a honra, a autonomia, a liberdade, o trabalho e o bem viver.

\section{Considerações finais}

Comecei esse artigo situando uma discussão sobre a colonialidade do poder na literatura latino-americana e como as questões postas por esse campo têm ressonância com a tradição de estudos sobre relações interétnicas no Brasil, em particular com a noção de friç̧ão interétnica elaborada por Cardoso de Oliveira. O ponto dessa ressonância seria a consistência da ideia de fricção interétnica e aquela do "colonialismo interno", esboçado pelo autor ainda na década de 1960.

O episódio etnográfico ocorrido na arena local em São João das Missões é uma situação exemplar dos produtos da colonização apontados por Quijano: um sistema de exploração da mão de obra e de servidão, que combina racialização das relações, imposição de um modelo de produção excludente e racista. Ao mesmo tempo, é um contexto de reivindicação de identidade e de movimento que balança os padrões de poder estabelecidos. Essa colonialidade do poder entra em crise quando o controle da autoridade coletiva é tomado por aqueles que deveriam ser submissos a ele.

A exemplo dos casos do Equador e da Bolívia, em que os indígenas desenvolvem um papel de protagonismo no campo político contemporâneo 
(PACARI 2004), a chegada de um indígena à prefeitura, a organização do grupo de "desaldeados", os direitos conquistados pelos indígenas face às condições de vida dos não índios de São João das Missões, constituem fatores significativos da situação atual e que despertam e atualizam imagens da mistura e da fronteira.

Observo que a experiência da etnicidade Xakriabá é um microcosmo da crise do colonialismo interno. Um movimento de descolonização das relações de poder que, de diferentes modos, visa eliminar a exploração e a servidão. Mas que também atinge questões existenciais para cada indígena na elaboração de uma forma de estar no mundo e experimentá-lo. Uma política decolonial está sendo vivida pelas novas gerações Xakriabá.

\section{Bibliografia:}

ANASTASIA, Carla Maria Junho. A Sediação de 1976: Estudo comparativo entre a zona dinâmica da mineração e a zona marginal do sertão agropastoril do São Francisco. Belo Horizonte. Tese de ciência política apresentada à Universidade Federal de Minas Gerais, 1983.

BARRETO F, Henyo T. Tapebas, Tapebanos e Penas-de-Pau de Caucaia, Ceará: Da etnogênese como processo social e luta simbólica. Série Antropologia 165, Brasília, Departamento de Antropologia, Universidade de Brasília, 1994.

BOURDIEU, Pierre. O Poder Simbólico. Rio de Janeiro: Bertrand Brasil, 1998.

BURTON, Richard. Viagem de canoa de Sabará ao Oceano Atlântico. Belo Horizonte, Ed. Itatiaia; São Paulo, Ed. Da Universidade de São Paulo, 1997.

CASTELLS, Manuel. O Poder da Identidade. São Paulo: Paz e Terra, 1999.

CARDOSO DE OLIVEIRA, Roberto. O Trabalho do Antropólogo. Brasília, Paralelo 15, São Paulo, Editora UNESP, 2000.

O índio e o mundo dos brancos. Campinas, SP: Editora da Unicamp, 1996.

"A noção de colonialismo interno na etnologia (1966). In: A Sociologia do Brasil Indígena. Rio de Janeiro, Tempo Brasileiro; São Paulo, Editora da USP, 1972.

CARNEIRO DA CUNHA, Manoela. "Etnicidade: da cultura residual mas irredutível". In Antropologia do Brasil: Mito, História, Etnicidade. São Paulo: Brasiliense, 1987. 
GLISSANT, Édourd. Poética da Diversidade. Juiz de Fora: Universidade Federal de Juiz de Fora, 2005 [1981].

GRUZINSKI, Serge. El pensamiento mestizo. Barcelona: Paidós, 2000 [1999].

NUGENT, Daniel. "Two, three, many barbarisms? The Chihuahuan frontier in transition from society to politics". In.: Contested ground: comparative frontiers on the northern and southern edges of the Spanish empire, Donna Guy e Thomas Sheridan, eds., págs. 182-199. Tucson: University of Arizona Press, 1998.

OLIVEIRA FILHO, João Pacheco de. Uma etnologia dos "índios misturados"? Situação colonial, Territorialização e Fluxos Culturais. In: Mana, vol. 4, 1998.

OLIVEIRA, Alessandro Roberto de. Política e políticos indígenas: a experiência Xakriabá. Dissertação de mestrado, departamento de Antropologia, UnB, 2008.

PACARI, Nina. "El auge de las identidades como respuesta política". In: Los desafios da la interculturalidad: identidad, política e derecho, Milka CastroLucic, ed. Santiago: LOM Ediciones, 2004 págs. 35-51.

PARAÍSO, Maria H. B. Laudo Antropológico. Identidade Étnica dos Xakriabá, 1987.

QUIJANO, Aníbal. "O 'movimento indígena' e as questões pendentes na América Latina". Política externa, 2004, 12(4): 77-95.

RAMOS, Alcida. Ethnology Brazilian Style. In.: American Anthropological Association, 1990.

SANTOS, Ana Flávia M. Xakriabá: Identidade e História. Relatório de Pesquisa. In: Série Antropologia, 167. Brasília: Departamento de Antropologia. Unb, 1994.

"Do terreno dos caboclos do Sr. São João à Terra indígena Xakriabá: as circunstâncias da formação de um povo. Um estudo sobre a construção social de fronteiras. " Dissertação de Mestrado apresentada ao Programa de Pós-Graduação em Antropologia Social da Universidade de Brasília. Brasília, 1997.

SAINT-HILAIRE, Auguste de. Viagem pelas províncias do Rio de Janeiro e Minas Gerais. Belo Horizonte: Editora Itatiaia Ltda, 2000.

SILVA, C. T da. Situações coloniais, pluralismo étnico e desafios da autonomia indígena na América Latina. Revista de Estudos em Relações Interétnicas 2015, V. 19. N.1 
STAVENHAGEN, Rodolfo."Terceira parte: Relações interétnicas e relações de classe em Centro-américa". Classes rurais na sociedade agrícola, M. André, trad. São Paulo: Edições Loyola1979 [1969].

TAUNAY, Afonso de Escragnolle. História Geral das Bandeiras Paulistas. SP: Imprensa Oficial, 11 volumes, 1948.

VASCONCELOS, Diogo de. História média de Minas Gerais. Belo Horizonte: Editora Itatiaia, 1974. 